\title{
Failure of oral D-penicillamine to modify adjuvant arthritis or immune response in the rat
}

\author{
S. P. LIYANAGE AND H. L. F. CURREY \\ The London Hospital, London, E.1 $1 B B$
}

Although the original rationale for testing penicillamine in rheumatoid arthritis (depolymerization of preformed rheumatoid factor) is no longer considered valid, this form of therapy continues to be tested, and recent reports (e.g. Jaffe, 1970; Camp, 1971) suggest that it may be clinically effective. For this reason and because previous animal studies have given no clear pointer as to how any such effect may be mediated, we have studied the effect of $D$-penicillamine on adjuvant disease and immune responses in the rat.

Ten Sprague-Dawley rats (150-230 g.) received $200 \mathrm{mg}$./kg. D-penicillamine hydrochloride (freshly dissolved in deionized water) daily by mouth from Day -4 to Day +20 . A matched control group received comparable doses of deionized water. On Day 0 all animals were injected both with Freund's complete adjuvant $(0 \cdot 6 \mathrm{mg}$. dried, heat-killed tubercle bacilli in $0.1 \mathrm{ml}$. heavy mineral oil) into a hind footpad, and with sheep erythrocytes $(1 \mathrm{ml} . \times 1$ per cent.) intraperitoneally. Rats were bled on Day +7 and the serum tested for total and 2-mercaptoethanolresistant haemagglutinins. Arthritis (excluding the injected limb) was scored daily from Day +11 . Tuberculin hypersensitivity was tested by measuring ear swelling $24 \mathrm{hrs}$ after an injection of $0.02 \mathrm{ml}$. of

1:10 PPD given on Day +14 . The results are shown in the Table.

\section{Comment}

Most of the reported animal experiments employed the DL form of penicillamine. Thus, Klamer, Kimura, and Makstenieks (1968) reduced the severity of rat adjuvant arthritis by 22 per cent giving this preparation in doses of $36 \mathrm{mg} . / \mathrm{kg}$./day. Hübner and Gengozian (1965) administered DL-penicillamine to mice parenterally in doses of about $200 \mathrm{mg}$. $/ \mathrm{kg}$./day and showed only a modest reduction in humoral antibody response to typhoid $\mathrm{H}$ antigen, an effect apparently mediated at a cellular level rather than by depolymerization of immunoglobulin.

The present experiments showed no inhibition of adjuvant arthritis or immune responses when D-penicillamine was given in relatively large doses (about ten times those used to treat rheumatoid arthritis in man). Adjuvant disease has proved a fairly sensitive model for testing most of the antiinflammatory and immunosuppressive drugs effective in the human disease. These negative results leave open the question of how D-penicillamine may act in rheumatoid arthritis.

Accepted for publication May 2, 1972

\begin{tabular}{|c|c|c|c|c|c|}
\hline \multirow{2}{*}{ Group } & \multirow{2}{*}{$\begin{array}{l}\text { Mean joint } \\
\text { score }( \pm S D) \\
\text { on Day }+15\end{array}$} & \multicolumn{2}{|c|}{$\begin{array}{l}\text { Haemagglutinin titre } \\
\left(\text { Mean } \log _{2} \text { recip. titre }\right)\end{array}$} & \multirow{2}{*}{$\begin{array}{l}\text { Mean ear } \\
\text { swelling } \\
(\mathrm{mm} .) \text { in } \\
\text { PPD test }\end{array}$} & \multirow{2}{*}{$\begin{array}{l}\text { Mean weight change } \\
\text { Day -4 to Day }+16 \\
\text { (g.) }\end{array}$} \\
\hline & & Total & $\begin{array}{l}2 M E \\
\text { resistant }\end{array}$ & & \\
\hline $\begin{array}{l}\text { Control } \\
\text { Penicillamine }\end{array}$ & $\begin{array}{l}19 \cdot 6( \pm 11 \cdot 7) \\
22 \cdot 0( \pm 10 \cdot 4)\end{array}$ & $\begin{array}{l}4 \cdot 4 \\
4 \cdot 5\end{array}$ & $\begin{array}{l}3 \cdot 7 \\
3 \cdot 9\end{array}$ & $\begin{array}{l}0.699 \\
0.653\end{array}$ & $\begin{array}{l}+26 \cdot 6 \\
+18 \cdot 4\end{array}$ \\
\hline
\end{tabular}

None of the penicillamine group results is significantly different from the control group figure at 5 per cent.

\section{References}

CAmp, A. V. (1971) Abstract 41.17 'VII European Rheumatology Congress. Brighton, June, 1971' (Preliminary report of a controlled trial of penicillamine in rheumatoid arthritis)

Hübner, K. F., And Gengozian, N. (1965) Proc. Soc. exp. Biol. (N.Y.), 118, 561 (Depression of the primary immune response by dl-penicillamine)

JAFFE, I. A. (1970) Arth. and Rheum., 13, 436 (The treatment of rheumatoid arthritis and necrotizing vasculitis with penicillamine)

Klamer, B., Kimura, E. T., And Makstenieks, M. (1968) Pharmacol., 1, 283 (Effects of oral cysteine, penicillamine and $\mathrm{N}$-acetyl-penicillamine on adjuvant arthritis in rats) 